Introduction: Television in the Afternoon

Rachel Moseley, Helen Wheatley and Helen Wood

Rachel Moseley is Associate Professor in Film and Television Studies at University of Warwick, UK and one of the investigators on the AHRC-funded project 'A History of Television for Women in Britain, 1949-1989'. She has published widely on questions of gender and identity in popular film and television as well as on lifestyle television. She is currently writing a book on constructions of Cornwall in film and television.

\title{
Helen Wheatley
}

Helen Wheatley is Associate Professor in Film and Television Studies at University of Warwick, UK and one of the investigators on the AHRC-funded project 'A History of Television for Women in Britain, 1949-1989'. She has published widely on television history, genre and aesthetics. She is currently writing a book on spectacle and visual pleasure on television

\section{Helen Wood}

\section{Abstract}

In this introductory essay, the editors of this special issue of -Critical Studies in Television explore the existing ways in which scholars have considered afternoon television, present data which demonstrates the historical distribution of and shifts in the genres of afternoon, and make a case for the contribution to the field offered by this collection of new essays. In the process, we call for an interrogation of commonly held assumptions about gender, genre and theme around the figure of the 'woman at home' 
MOSELEY, WHEATLEY AND WOOD: 2

which have tended to be made about the programming scheduled at this time of day, and which the essays here begin to do through carefully historicised, close analytic work.

Keywords: address, afternoon, everyday, housewife, schedule, women

These days it seems retrograde to think about television through the organisation of the schedule, despite the fact that the industry still works hard to secure it, and that viewing figures are nurtured through prime scheduling space. As television scholars, we have become much more interested in the way that television has been liberated from time and space as it has been converted to digital media to be downloaded to various devices, avoiding the television set altogether. This is despite evidence from viewers' use of social media and programmes like Gogglebox (2013-present) which insist on the significance of co-presence and the schedule ${ }^{\mathrm{i}}$. Yet at the centre of traditional arguments about the specificity of television has been its particular relationship to spatio-temporal arrangements: the domestic space of consumption and its quotidian rhythms. As Brunsdon has argued, the configurations of 'woman', and more specifically 'the housewife', have been central to that narrative, and it has been central to the feminist research agenda on soap opera ${ }^{\text {ii }}$. However, we have rarely reflected on the shifting status of those definitions throughout broadcast history or their relationship to other genres. In this special issue, we take the afternoon as a specific scheduling slot through which there has been, and continues to be, a deliberate and shifting address to women at home. This allows a particular purchase on the historically struggledover category of woman and the related, often contradictory, discourses of feminism and femininity. Importantly, this special issue of Critical Studies in Television also makes a case for historical television research to look back at programming rendered invisible by the turn 
MOSELEY, WHEATLEY AND WOOD: 3

away from the everyday and the ordinary and towards the 'high end', 'quality' content that thrives in the broader digital environment.

'Daytime' television has not really been noted for its critical acclaim, relying mostly on a diet of soap opera, magazine programmes, quiz shows and talk shows, as well as news, sport, and schools' programming. 'Daytime' is a remarkably broad portmanteau term for a large portion of the broadcast schedule. Despite the shifts towards personalised viewing arrangements, and the consequent side-lining of issues related to scheduling, 'daytime' has retained its stigma as television content of low cultural value. In 1996 British critic Polly Toynbee wrote of the daytime magazine show:

It is Stupidvision - where most of the presenters look like they have to pretend to be stupid because they think their audience is. In other words it patronises. It talks to the vacuum cleaner and the washing machine and the microwave, without much contact with the human brain. ${ }^{\mathrm{iii}}$

More recently, actress Diane Keen, star of the popular BBC daytime soap Doctors, hit out against the devaluing of daytime drama in comparison to the drama of primetime, as the soap reached its $10^{\text {th }}$ anniversary with viewing figures peaking at around 3 million. ${ }^{\text {iv }}$ So, if television content really were an entirely movable feast in the era of downloading, PVRs and box-set bingeing, why should its timing still matter so much? Given that most afternoon programming is not the type of content that makes it onto personal programme planners, or can be purchased as a box set, or is likely or even possible to be downloaded as whole series, it is clear that this programming is still firmly stitched to the environment of the everyday in the apparent 'ghetto' of the daytime. Furthermore, this is regular, everyday television which, 


\section{MOSELEY, WHEATLEY AND WOOD: 4}

in our rush to redefine the medium in critical terms, has been significantly overlooked, despite its persistent place in the broadcast schedules.

Brett Mills ${ }^{\mathrm{v}}$ in this journal has discussed the problem of 'invisible television' with a special issue that brought to our attention the long-running, high rating shows that have been ignored by the academy. Of Mills' list of top ten (British) 'invisible television shows', which included Emmerdale and Top Gear, none were from daytime television. One of the criteria for the list is that these programmes should have had viewing figures of around 6 million in the UK. This suggests another category of even more invisible programming, since these figures are really only achievable at primetime. Mills goes on to discuss the way in which our academic working practices and tastes can work to figure the history of television in particular ways which privilege those television shows that are innovative, spectacular and international in reach, leaving behind the ordinary, the everyday and the nationally familiar. He argues that 'in seeking out the new, I am suggesting we downplay the significance of the old, the ongoing, the repetitive, the always there'. ${ }^{\text {vi }}$

Mills' call is to 'reclaim the popular' and to insist upon the popularity of television as still, despite all the technological innovation, the mass medium par excellence. This is in some ways a return to Frances Bonner's intervention into 'ordinary television' where she groups together shows such as magazine and lifestyle programmes, populated by ordinary people, and interrogates their very familiarity and everydayness. ${ }^{\text {vii }}$ These are shows that have been excluded from much academic enquiry for their perceived lack of 'substance' in comparison to, for example, 'serious drama ${ }^{\text {viii }}$ or current affairs. But even for Bonner, 'time 
MOSELEY, WHEATLEY AND WOOD: 5

of day' shows are a problem category for their lack of 'satisfactory names', despite them being common to most broadcasting systems and often consisting of a combination of elements of chat and performance. They are the very meat of most broadcasting schedules and, by virtue of their very everydayness, they are also the most easily ignored.

These interventions are useful to our claim for making visible programming that is not often represented in the critical work on television. However, our purchase here places greater emphasis on the rhythmic as well as the familiar quality of everyday life. Whilst many of the shows discussed in this issue had relatively high ratings, our aim is not necessarily to reclaim the popular; rather, it is to emphasise time as an analytic category with which to approach television. In bringing together the research in this special issue, we install an approach that insists upon the relevance of ritual, of repetition and of longevity, elements that constitute the 'dailiness' of broadcasting, ix and the work here emphasises the relationship of this programming to a particular mode of address. We follow on from a precedent set in the work done by the Midlands Television Research Group on the 8-9pm slot in Britain, as a methodological attempt to think about the 'textuality of television in ways that are specific to television'. ${ }^{\mathrm{x}}$ Brunsdon et al argue that programme categories and genres can conceal the 'institutional and nationally timetabled aspects of programmes'. ${ }^{\mathrm{xi}}$. Therefore this collection of essays is an attempt to firmly re-embed television programmes within the broadcast environment, and in relation to a space in the schedule which has retained a marked, if shifting, mode of address, particularly to women at home. This allows us some historical purchase on how the slot has changed over time, as well as helping us to 'unearth significant programming activities that seem to have faded from memory' ${ }^{x i i}$. In doing so, this special 
issue of Critical Studies in Television is not just aiming to rescue programmes from invisibility, but is also attempting to offer more historical detail about which programmes have been aired in the afternoon, in an attempt to trouble any popular memory of afternoon programming's association with the feminine as necessarily banal and mundane.

\section{The Housewife in the Afternoon}

All the essays assembled here take as their focus weekday 'afternoon' programming from

within the broader category of 'daytime'; whilst focusing on a particular time span within the schedule is a relatively uncommon approach within television scholarship, schedule-focused studies have been more usually concerned with primetime. ${ }^{\text {xiii }}$ In the UK, television in the afternoon has been consistently part of the British television schedule since the beginnings of the television service, although the number of hours that constitute this afternoon slot have varied.

An important landmark in the history of the afternoon schedule in the UK was the establishment of the BBC's Women's Programme Department between 1953 and 1964, which further established the afternoons as having a regular and deliberate address to women. ${ }^{\text {xiv }}$ In the US, Lynn Spigel has documented the experiments with a regular daytime schedule in the US as being initiated by DuMont to try and offset its economic losses in prime time. By 1949, DuMont was transmitting the first commercially sponsored, daytime network show, Okay Mother (1949-1951), to three affiliates and also airing a two-hour afternoon programme on a full network basis. This was later followed by afternoon programming from the other big networks CBS and NBC in $1951 .{ }^{\mathrm{xv}}$ Spigel describes a highly volatile commercial US market competing for audiences and sponsors, whilst Thumim charts a period in the early fifties 


\section{MOSELEY, WHEATLEY AND WOOD: 7}

where the daytime was essential to establishing the British audience for television as it grew into maturity. At the centre of the both of these narratives of innovation is a conscious address to 'the housewife'.

According to Janet Thumim:

The engagement of the female audience was thus central to at least two aspects of the emergent institution: women's support was assumed to be crucial in embedding habits of viewing into domestic routines, and the majority of early advertising was for small domestic consumables typically purchased by women - items such as soap powders, convenience foods, and the plethora of new appliances coming to the domestic market in the later 1950s. ${ }^{\mathrm{xvi}}$

Television executives and programme makers in the UK and the US thought carefully about the schedule of the home: at what time husbands and children left for work and school, when most domestic chores got done, when toddlers took naps and older children returned home from school. The BBC's audience research files show evidence that this was carefully explored. ${ }^{\text {xvii }}$ The afternoon schedules in the post-war period and beyond, therefore, needed to reflect what was happening in the home, but in the 1950s they were also an effort to win over women to television in their prime role as 'Mrs. Consumer'. According to Spigel,

In assuming the role of "consumer educator", the networks went beyond just teaching housewives how to buy advertisers' products. Much more crucially in this early 
MOSELEY, WHEATLEY AND WOOD: 8

period, the networks attempted to teach women and their families how to consume television itself.

Television in the afternoon was thus a struggle over domestic routine. On the one hand programming content attempted to fit into existing household rhythms, and on the other, it wanted to change them, so that television viewing became a firm daily habit. As Brunsdon points out, it is Carol Lopate who first attends to the question of the daytime schedule's position within the quotidian rhythms of the housewife's day: Lopate's argument that the 'heartbreak, confusion, restrained passion, and romance of families in the soaps provides the anaesthesia to fill out the hollows of long afternoons when children are napping and there is ironing or nothing at all to be done' shows a sensitivity to the ways in which the formal and narrative identity of afternoon programming 'fits into' the patterns of everyday life. ${ }^{\text {xix }}$ Television re-imagined and reconfigured the everyday in very powerful ways and the afternoon magazine show was crucial to this formation, since it offered the kind of fractured schedule of short pieces of information and entertainment entwined with a conversational address that was able to connect with the distracted housewife. For instance Lynn Spigel describes Pat n Johnny, a programme aired in 1950 on Detroit's WXYZ which was less than subtle in solving the housework-TV conflict by Johnny Slagle announcing at the beginning, "Don't stop what you are doing. When we think we have something interesting I'll blow this whistle or Pat will ring her bell." ${ }^{x x}$ Rather than competing with her chores, the magazine show could possibly even help her to accomplish them, with content that placed an emphasis on instruction and which, given the centrality of talk in daytime programming, could often be followed without carefully watching the set. There are numerous magazine shows that are relatively absent from television histories, all of which address women in the daytime and 
MOSELEY, WHEATLEY AND WOOD: 9

which make their domestic responsibilities central, such as the BBC's For the Housewife (1948) About the Home (1951-8), or Family Affairs (1960), which have been uncovered in feminist historical work. ${ }^{\mathrm{xxi}}$

This historical evidence builds up a picture of what we expect of afternoon programming, heavily influenced by the image of 'Mrs. Daytime Consumer' as the viewer. It presents a form of address neatly tied up with the figure of the housewife that has been reinforced by audience research filling in the details of how women use television around their domestic responsibilities. For instance, Dorothy Hobson's research conducted in the late 1970s described how radio and television help structure the otherwise structure-less day of the home, and her later work on the afternoon soap opera Crossroads suggested that television viewing should be seen as a distracted activity as it is sutured to the multi-tasking of domestic labour and child care. ${ }^{x x i i}$ But this image, as it has endured, has not often been reinterrogated. For instance, any straight-forward relationship between television and 'the housewife' does not quite capture the tensions over the broadening class composition of the expanding audience during the 1950s. The inferences to 'home' assumes one untroubled by the fact that many women left their homes during the war, or that women were increasingly assuming more public lives ${ }^{\text {xxiii }}$. As we move into the $60 \mathrm{~s}$ and 70 s, the afternoon address to women must surely register the broader socio-political climate, given the rise of the civil rights movement and feminism and their influence over popular culture (see Jilly Boyce Kay's discussion in this collection about how a 1970s British magazine programme negotiated its address to men, working women and shift-workers). Just because afternoon programming was originally conceived around women's daily domestic labour, it does not 
necessarily follow that the programming was always mundane because the work was mundane, nor that the nature of this labour has not changed over time. As feminism has consistently reminded us, the personal is a site of political struggle making the home a contested and complex site of negotiation.

Janet Thumim and Mary Irwin have established the efforts of Doreen Stephens, as a feminist, former MP, and the first editor of Women's Programmes at the BBC to push programming for women into directions beyond the domestic. ${ }^{\text {xiv }}$ Thumim references Stephens' desire to address both 'Mary and Martha': the housewife that needs a rest from her domestic chores as well as the housewife who requires stimulation from their monotony. ${ }^{\mathrm{xx}}$ There is, therefore, evidence that the address to women in the 1950s was more complex and attended to the different needs of different women at the time. ${ }^{x x i}$ For instance, this plural address is seen in this description of Your Own Time (1955-58) a BBC magazine afternoon programme for younger women:

Designed especially to help the young married woman who is tied to her home by domestic responsibilities to maintain a pride in her appearance despite the budget limitations by increasing her knowledge of current taste in fashion and beauty fields; to keep her in touch with the outside world of affairs, entertainment, literature and art, and to establish a background of information and taste to which any new developments can be compared. ${ }^{\text {xvii }}$

Irwin's archival research on the work of Stephens reveals how, behind the loose label of 'magazine show', she pursued extremely diverse content, offering, for instance, features on political figures, arts content and discussion of women's dilemmas as part of broader social 
issues. Stephens did this whilst fighting against budget constraints, the prejudices of senior male executives and difficulties in getting talent for afternoon programming. ${ }^{\text {xxviii }}$ Yet even Stephens wanted to get women's programming moved to a more prestigious time slot in the evening, since it seemed that it was time on the schedule, and all that it implied about women, that was proving the biggest hurdle.

\section{The Afternoon Schedule}

The existing historical research on women's afternoon programming of the 1950s suggests programme content that is more diverse and experimental than we might expect, or than is often remembered. Mary Irwin documents formats and styles that some may presume were much later in invention, especially since we have witnessed the rise of lifestyle in the 1990s, and the migration of their formats to primetime. ${ }^{\text {xix }}$ But what has occurred in the large intervening period, through the 1960s, 1970s and 1980s? We try to fill in some of that picture in this introduction and in the essays collected in this special edition, by taking the afternoon as our analytic point of focus. We consider the rhythm of the afternoon, as a moment of reflection or rest, after the business of the morning, and as a slot that has featured magazine formats and discussion programmes, soap operas, documentary, sport, and the news. These various genres sharing in this space on the schedule must offer a textual sensitivity to the time of the day: to ritual, and to the personal, intimate terrain of the quotidian. Many of these forms of programming are loosely organised around a mode of address that assumes a feminised persona: this persona is, however, more complicated than the assumed figure of the 'housewife' and which is sensitive to the shifting contours of historical and industrial change. 
In researching the history of the afternoon schedule, we took a quantitative 'snapshot' that surveyed this slot on BBC1 and ITV from their beginnings, in weekdays across two weeks (the first week of May and first week of October) at five year intervals, and tracked the generic changes in programming by analysing the extent to which they appeared in the schedule. We did this in order to gain a concrete sense of the rhythms and generic makeup of the afternoon slot beyond the hyperbole of lazy journalism bemoaning the banality or homogeneity of this part of the schedule. The weeks in question were chosen as typical, rather than exceptional in the annual broadcasting calendar, though this decision was problematised on a number of occasions by the fact that the first Monday of May sometimes featured special May Bank Holiday programming (and thus more films or sport than might otherwise be broadcast usually) and also the October week was sometimes dominated by lots of news OBs from the political party conferences. The afternoon was defined as starting at the first full adult programme after midday and finishing at the afternoon closedown or the start of children's programming. In undertaking this research, Helen Wheatley returned to the method she used as part of the Midlands Television Research Group's 8-9 project to quantify generic change over a long period of time in relation to a particular slot in the schedule ${ }^{\mathrm{xxx}}$.

Twelve generic categories were used:

News - which included current affairs programming, outside broadcasts of royal events and political party conferences, and weather. 
Children's programming - which was only counted when it was sited within the afternoon slot and not annexed at the start or end of the afternoon

Instruction - which included crafting, hobbies, cookery, fitness (mainly yoga), consumer programmes, and lifestyle programming. Unsurprisingly, instruction shifted toward 'lifestyle' at the beginning of the $90 \mathrm{~s}$.

Magazine - which was mainly made up of long running magazine programmes e.g. Designed for Women (1947-1951), Good Afternoon (1971-1988), Pebble Mill at One (1972-1996). This category also included chat shows, a programming type which became increasingly common in the afternoon slot in the mid 1990s.

Drama - which included imports of serial drama, UK produced serial drama, and anthology drama. Genres of drama that frequently appeared included light crime/action-adventure, and also family dramas, melodrama and romance.

Soap - which was counted as a separate category from Drama, though sometimes the limits of these two categories were difficult to define. 
Light Entertainment - which included variety entertainment programming ('shiny floor shows' as they are known in the industry), but also, and increasingly, panel and quiz shows, and programmes about the entertainment industries.

Documentary - which included lots of documentaries on the UK and other countries, but also history documentaries, natural history etc. This category also includes other light documentaries, and from 2005 this category also incorporates a bit of reality television.

Film - which included those films that had previously had a theatrical release.

The other self-explanatory categories were: Sport, Sitcom and Schools Programming.

\section{INSERT TABLES HERE - SEE ATTACHED DOCUMENT}

The first, and most obvious finding from this research, was that the afternoon schedule was more generically diverse than we might have thought. Throughout the history of the slot, news, sport, current affairs programming and documentary sit alongside magazine programming and instruction mainly directed at women, as well as soap and other drama (both anthologised and serials/series, made domestically and imported, with no particular bias towards programming obviously 'for' either gender). At various points, particularly in the 1960s, 70s and into the early 80s, this snapshot research revealed that the afternoon slot on both channels was largely taken up with schools programming, an address and use of 
television in the afternoon which is at odds with the commonly held belief that this part of the schedule is, and has always been, 'for women'.

It is interesting that our 'snapshot' statistical analysis of this slot revealed that sport has played such a large part in the afternoon schedule, particularly on BBC1: in the mid sixties and early seventies roughly a third of the channel's afternoon schedule was taken up by sports programming (commonly horse racing, golf, athletics and football); in 2010, nearly half of the $\mathrm{BBC}$ programming surveyed was sports programming, and at times of international sporting events the afternoon schedule can be filled with sports programming alone. In other parts of our research AHRC funded project, 'A History of Television for Women in Britain, 1947-89', sport has emerged as more significant category in women's relationship to television than might have been previously thought. For instance, research at the Mass Observation archives shows that in the 1949 Mass Observation Bulletin No 30, a survey report into what people thought of owning a television set, sports broadcasts were described as one of the major appeals of the new medium, for women as much as men: 'I have seen television transmission and think it is wonderful especially for the actualities and outside sporting events' ( 42 year old woman clerk). ${ }^{\text {xxi }}$ Classic audience research by David Morley and James Lull has generally reinforced the idea of sports as a male preference. ${ }^{\text {xxii }}$ However the findings of Hazel Collie's audience research, which interviewed women across generations as part of this AHRC project, have shown a more complex picture. Whilst sportsviewing was sometimes resented as the masculine dominance of choice, it was also described in terms of sharing moments of intimacy with fathers as well as husbands, and as a site of 
female desire, especially in discussions of tennis at Wimbledon. ${ }^{\text {xxxiii }}$ There is clearly another narrative of women's relationship to televised sport to be told, to which the dominance of sport in the afternoon schedules might be significant.

The picture of factual programming we uncovered was also interesting. If we combine the statistics for news and current affairs with those for documentary (i.e. 'serious' factual programming), we find that in the years 1955, 1975, 1980, 2000 and 2005 these genres of programming were most common on ITV during the weeks under consideration; it is not until 2010 and 2013 that the factual entertainment genres of magazine/chat shows and instruction/lifestyle programming become more popular (on ITV in 2010 these amalgamated factual entertainment genres made up a massive $71 \%$ of the schedule, partly fuelled by the expansion of lifestyle programming from primetime back into daytime on this channel at this time). On $\mathrm{BBC} 1$, magazine/chat shows and instruction/lifestyle programming have been more consistently present throughout the history of the slot, particularly magazine and 'instruction' programming; indeed, as this snapshot research reveals, it was only in the late 1930s (where drama was the most common form of programming in the afternoon and prior to the establishment of the Women's Programme's Department), the mid 60s and early 70s (at the height of the BBC's afternoon programming for schools) and in 2000 that these programmes were not in the 'top three' generic categories of programming on $\mathrm{BBC} 1$.

The research revealed a definite surge in dramatic programming of all kinds at the point at which schools programming disappeared from the afternoon schedules of $\mathrm{BBC} 1$ and ITV in the mid 1980s. Whilst soap opera appears in the ITV afternoon schedules from an earlier point (around a quarter of the 1965 afternoon schedule on ITV was made up of soap 
opera, largely due to the daily broadcasts of Crossroads, it is not until the early 1990s when afternoon soap (both domestic and imported from the US and Australia) dominates.

Throughout the 1990s, soap opera made up about a third of the afternoon schedule (and nearly half of ITV's schedule alone), replacing both 'serious' factual documentaries and factual entertainment in the schedule.

What does this statistical 'snapshot' research mean for the categorisation of afternoon programming as 'for women'? If we consider the genres of programming most commonly understood as being 'for women' together (soap opera, magazine programming, lifestyle, instructional or hobbyist programmes), we see that apart from in the very first years of broadcasting and at the height of the afternoon schools' schedule, they make up between 15 and 51 per cent of the total combined broadcasting hours of ITV and BBC1, and were the most common form of programming in half of the years surveyed. We can see that programming primarily aimed at women became increasingly important on these two main channels as other forms of programming migrated elsewhere in the schedule, as broadcasting hours were expanded and the provision of other mainstream, and then specialist, channels was increased. Of course looking at this quantitative data only tells us so much; it doesn't reveal the nuances of gendered address within genres such as light entertainment and drama, or even within afternoon news programming (see Gillian Murray's article in this volume, for example). However, it does show us that programmes made specifically for women have had a near continuous presence on British afternoon television since the pre-war broadcasting era, from which we may surmise that a broader address to this viewing constituency might be found by looking more closely at the programmes themselves. 


\section{The Textual and the Everyday}

The content and rhythm of afternoon programming has mutated over the years. Programme titles have moved on from addressing the housewife as directly as they did in the 1950s and the generic make-up of the afternoon is more diverse than that normally considered as for women. However there are two things to consider here. The first is that the category of 'women's programmes' may be more diverse than we might presume, and secondly, those programme genres that have normally been categorised as 'for' women have retained a remarkably consistent presence in the afternoon schedules, to a greater and lesser extent throughout the history of this slot. Therefore, it is not genre which unites the programmes discussed in this special issue, because they span soap opera, magazine programmes, news and documentary; rather, we are interested in their place in the schedule which is suggestive of their potential mode of gendered address. This, we hope, will bring to light some of the historical shifts and movements in the way in which woman as a category has been negotiated on afternoon television both through time and in relation to other figurations of women in different periods. For instance, the essays here place the enduring legacy of 'the housewife' in a dialectic relationship with the feminist of the 1970s, the aspirational working woman of the 1980s as well with the 'public roles' of women presenters on television.

In editing this collection we hope to undermine some of the assumptions around the 'everyday' and television, and to challenge the popular conception of this slot as necessarily banal. In Henri Lefebvre's most cited work, it is the everyday's attachment to the taken-for- 
granted and repetitive which can prevent us from seeing its precise structure and formation.

For Lefebvre, 'everyday life weighs heaviest on women... some are bogged down by its particular cloying substance, whilst others escape into make believe...They are the subjects of everyday life and its victims. ${ }^{\text {'xxiv }}$ Rita Felski takes issue with this version of everyday life which produces women as trapped within the daily repetitiveness of the home, unable to evaluate their circumstances, and therefore somehow outside of the movement of history. She urges us to recognise the home as the productive site of women's efforts and labour that should not be sanitised by theories of the everyday, but rather enlivened by seeing how routines might 'strengthen, comfort and produce meaning'. ${ }^{\mathrm{xxv}}$

There was of course a similar reworking of the relationship between routine as restrictive and also reassuring in the feminist work on soap opera by Modleski and Brunsdon, and in particular how it worked through elements of the text: lack of narrative closure, intertwining plots and so on. ${ }^{\text {xxvi }}$ The features of routine, repetition and their rhythmic quality were not simply to be overlooked as part of the confines of domestic, but rather explored in terms of their analytic power for explaining the relationship between textual properties and the subject of women and in television's role in brokering the private/public distinction. Sadly work on soap opera seems to have faltered, leading Christine Geraghty to make a plea for greater understanding the historical specificity of shifts in soap opera, ${ }^{\mathrm{xx} x \mathrm{ii}}$ a plea to which Elana Levine's contribution here responds. 
In Felski's feminist re-evaluation of the everyday, she reminds us that it should 'not be conceptualised as homogeneous and predictable terrain. It embraces a diverse range of activities, attitudes and forms of behaviours' ${ }^{\text {xxxviii }}$. Perhaps in its attachment to the everyday the magazine format also insists on some diversity as its familiar template can invite a range of perspectives and positions, as suggested by those re-evaluating the work of Doreen Stephens, and in Jilly Boyce-Kay's research on Good Afternoon! in this collection. If 'habit is the necessary precondition for impulse and innovation' ${ }^{\text {xxxix }}$ then possibly within some of the repetitive formats there is space for programming which can move beyond a conventional image of the 'housewife' towards more diverse figures of womanhood that are simultaneously domestic and also part of the structure of modern public life. If afternoon news creates a space where the housewife becomes a legitimate speaking subject, as Gillian Murray suggests here, then we might have to diversify some of our understandings of the relationship between television and the 'confines' of the home. Just as the movement of soap opera generates a melodramatic tension over what will happen next, perhaps there is space for some unpredictability in the content of afternoon television after all. It is not that we want to overstate the case by suggesting some reactionary critique of afternoon television: it is not to be too easily condemned or celebrated. We are, though, suggesting some historical attention to detail around television's form of address, its time of broadcast and its complicated conversation with any idea of woman at home, over a period in which the spaces of home and public life were being re-interpreted, in part by television itself.

\section{A Closer Look at Afternoon Television}


We think that the essays collected in this special issue of Critical Studies in Television represent a significant contribution to the field of feminist television studies on both sides of the Atlantic. The issue addresses programming genres understood as 'low status' - soap, talk, magazine programming - in a move which is typical of the wider field. These five pieces, however, move that field forward significantly through their careful attention to the historiography of the regional, the significantly under-theorised periods of the 1960s, 1970s and early 1980s and, in the British context, of ITV programming rather than that produced by the BBC.

In her piece on the 'supercouple' of 1980s US daytime soap opera, Elana Levine offers a much needed historicisation of this key genre in feminist television studies. While existing soap opera scholarship has tended to focus on the contemporary, Levine's essay for this collection demonstrates the flexibility of the genre in responding to both shifts in industry and the desire to broaden to soap audience, but also in responding to socio-cultural shifts around second-wave feminism. Through her discussion, she shows how daytime soap changed formally as well as thematically, in its turn away from the more socially aware concerns of 1970s serials. The formation of the daytime soap 'supercouple' of the early 1980s, she contends, can be understood as a negotiation of feminist politics which resonated with a nascent postfeminist sensibility as well as with the turn away from explicit feminist discourse; the 'supercouple' simultaneously understood feminism as having taken place, whilst reinforcing key ideas about gendered and classed identities.

Jilly Boyce-Kay's essay is also concerned to historicise a key genre within 'women's television', the British afternoon magazine programme, and to address key gaps in the field of British television studies: programming of the 1970s and ITV provision. Taking the example of Thames Television's Good Afternoon!, Boyce-Kay shows how British television history has been shaped by the shifting technologies and spaces of the archive. She demonstrates 
how the popular history of this programme typically elides its ongoing attention to matters of serious public import, thereby reproducing ideas about women's programmes' focus on subject matter perceived as lighter and more traditionally feminine. The essay draws attention to the ways in which this programme exhibits the instability of the term 'women' through an examination of the programme as well as its contemporary paratexts, and to what she describes as the complexity of afternoon television's role in gender politics and 'the difficulty in understanding the dynamic relationships between "women's genres" and public feminism'. Through her analysis, Boyce-Kay engages directly with the historically specific politics of the space of the afternoon schedule.

Gillian Murray's piece makes use of the holdings of the Media Archive of Central England to explore the ways in which ATV Midland's afternoon news programming constructed and addressed the subject understood as 'the mass housewife'. In a fascinating comparison of examples from spot advertisements, admags and news magazine programmes, Murray reveals the ways in which representations of 'the ordinary housewife' both resonated with and interrupted the dominant contemporary image of the mid-twentieth century housewife, thereby tracing the emergent shifts around class and generation which were being felt in postwar British society. Offering the 'housewife' as speaking subject to contemporary news and public life is a position infrequently explored in the typical construction of the housewife in relation to consumerism. At the same time, through an analysis of ITV scheduling trends and the examination of specific examples, this piece enables us to see the ways in which the boundaries between afternoon and evening programming were becoming increasingly permeable in an acknowledgement of women's shifting availability to view as a result of altered labour patterns inside and outside the home. 


\section{MOSELEY, WHEATLEY AND WOOD: 23}

Laurel Forster's examination of Southern Television's 1970s afternoon talk programme Houseparty (1972-1981) positions it as a programme which occupied the same psychic space as the viewer at home: attempting to negotiate a position between the two key female figures of the 1970s, the feminist and the housewife ${ }^{\mathrm{xl}}$. Forster demonstrates the ways in which both formally and thematically, Houseparty can be shown to have resonated powerfully with the positionalities being developed in feminist magazines like Spare Rib, walking a line between adjusted takes on traditional feminist crafts and interests, making the personal political and the consciousness raising techniques of the Women's Liberation Movement. Through her analysis, Forster shows the formal construction of an inclusive, potentially feminist address to the viewer at home in this instance of afternoon television for women of the 1970s.

In conclusion, this special issue revisits, rethinks and historicises genres that have been central to debates in feminist television studies, such as soap and talk, but also attends to those which have remained out of sight, such as news. Reading across the contributions here, we think that a more nuanced picture emerges of the ways in which the 'housewife', the figure around which so much feminist discussion has centred, both in the field and in academia, has been produced and addressed by afternoon television in particular; the debate over her meaning is visible both within and between the essays. What we hope to present here, then, is an enriched and complicated picture of 'afternoon television', its engagement with and response to social change and particularly to the development of feminisms, as well as a powerful sense of the programming that has occupied this under-researched space in the schedules.

\section{Appendix}

Crossroads (ATV/ITV/UK, 1964-1988) 
MOSELEY, WHEATLEY AND WOOD: 24

Designed for Women (BBC/UK/1947-1951)

Emmerdale (Emmerdale Farm) (Granada/ITV/UK/1972-present)

Comment [hw1771]: Helen Wh has 1949-51 - a doc from Mary has 1947 and the Teletronic site has 1949 but looking at it its vague - so I think I

would trust you Rach 1947-51

Gogglebox (Studio Lambert/All3Media/Channel 4 Television Corporation/Channel

4/UK/2013-present)

Good Afternoon (Thames Television/ITV/UK/1971-1988)

Houseparty (Southern Television/ITV/UK/1972-1981)

Okay Mother (DuMont, WABD, 1949-1951)

Formatted: Font: Not Italic

Pat n Johnny (WXYZ/US/1950)

Pebble Mill at One (BBC One/UK/1972-1996)

Top Gear (BBC One/UK/1978-present)

Your Own Time (BBC/UK/1955-1958) 
MOSELEY, WHEATLEY AND WOOD: 25 
MOSELEY, WHEATLEY AND WOOD: 26 
MOSELEY, WHEATLEY AND WOOD: 27

${ }^{\text {i }}$ See Helen Wheatley ‘Television Tribes', http://cstonline.tv/television-tribes, 25 November 2013.

${ }^{\text {ii }}$ Charlotte Brunsdon The Feminist, The Housewife and the Soap Opera, Oxford University Press, 2000.

iii From the Radio Times, reported in The Independent 7/5/96.

iv ‘Diane Keen Attacks Stigma of Daytime Television' The Telegraph 24/3/10: 'I often see things on in the evening and wonder how on earth it actually ever got made in the first place. There is stuff you watch and you think, "that was so bad, how did they get that on?" And then you have a show like this that is so consistently of a high standard and totally unafraid to deal with very difficult issues.'-

${ }^{v}$ Brett Mills, 'Invisible Television: The Programmes that No-One Talks about Even Though Lots of People Watch Them' Critical Studies In Television, 5, 1, 2011

${ }^{\text {vi }}$ Ibid, 7

${ }^{\text {vii }}$ Frances Bonner Ordinary Television, Sage, 2003

viii John Caughie, Television Drama: Realism, Modernism and British Culture, Oxford University Press, 2000

${ }^{\text {ix }}$ Paddy Scannell, Radio, Television and Modern Public Life, Blackwell, 1996. 
${ }^{\mathrm{x}}$ Charlotte Brunsdon, Catherine Johnson, Rachel Moseley and Helen Wheatley, 'Factual

Entertainment on British Television: The Midland TV Research Group's 8-9 Project'

European Journal of Cultural Studies 4, 1, 2001, 29-62.

${ }^{x i}$ Ibid, 30.

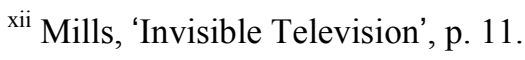

xiii For example Todd Gitlin Inside Prime Time, University of California Press, 1994; Bonnie Dow, Prime-Time Feminism, University of Pennsylvania Press, 1996, and Charlotte Brunsdon et al 'Factual Entertainment on British Television', 2001.

${ }^{\text {xiv }}$ For accounts see Joy Leman, 'Programmes for Women' in 1950s British Television' in Baehr, H and Dyer, G,(eds) Boxed In: Women and Television, 1987, pp. 73-95; Thumim, Inventing Television Culture, 2004; Mary Irwin, 'What Women Want on Television: Doreen Stephens and BBC Programming for Women, 1953-1964' Westminster Papers in Communication, 3, 3, 2011, 99-12.

${ }^{\mathrm{xv}}$ Lynn Spigel Make Room For TV: Television and the Family Ideal in Postwar America, University of Chicago Press, 1992.

${ }^{\text {xvi }}$ Thumim, Inventing Television Culture, p. 25

xvii E.g. 'Timing and Frequency of Programmes for Women, Children and Infants', Feb 1950 9VR/50/94 and 'An Enquiry about Afternoon Television Programmes' 2 Nov 1955 
(VR/55/516) and 'Women's Programmes on Television' 1959 (VR/59/364) Written Archives

Caversham cited in Thumim 2004.

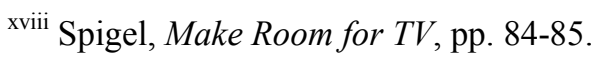

${ }^{\text {xix }}$ Carol Lopate 'Daytime Television: You'll Never Want to Leave Home', Radical America,

11, 1, 1977, 33-51; Brunsdon, The Feminist, The Housewife, 55.

${ }^{\mathrm{xx}}$ Ibid, 78.

${ }^{\text {xxi }}$ Leman, 'Programmes for Women', 1987, Thumim, Inventing Television Culture, 2004,

Irwin, 'What Women Want on Television' 2011.

xxii Dorothy Hobson, 'Housewives and the Mass Media' In Stuart Hall et al Culture, Media,

Language, Hutchinson, 1980 and Dorothy Hobson, Crossroads - The Drama of a Soap

Opera, Methuen, 1982.

${ }^{\text {xxiii }}$ As explored in Rachel Moseley, 'Marguerite Patten, Television Cookery and Postwar

British Femininity', in Stacy Gillis and Joanne Hollows (eds) Feminism, Domesticity and

Popular Culture, Routledge, 2008, pp.17-31.

${ }^{\text {xxiv }}$ Thumim, Inventing Television Culture, 2004 and Mary Irwin, 'What Women Want on

Formatted: Font: Times New Roman, 12 pt

Formatted: Font: Times New

Roman, 12 pt

Formatted: Font: Times New

Roman, 12 pt, Italic

Formatted: Font: Times New

Roman, 12 pt

Television: Doreen Stephens and BBC Programming for Women, 1953-1964' Westminster

Papers in Communication, 3, 3, 2011, 99-122.

${ }^{\mathrm{xxv}}$ Thumim, Inventing Televisin Culture, 2004, p. 91, Doreen Stephens interview for Aerial, 1955. 
${ }^{x x v i}$ Melanie Bell has made a similar argument in relation to contemporaneous women's cinema: Melanie Bell, Femininity in the Frame: Women and 1950s British Popular Cinema, I. B.Tauris, 2010.

xxvii Radio Times, Autumn 1955, probably Doreen Stephens cited in Thumim, 2004.

xxviii Irwin, ‘What Women Want on Television', 2011.

${ }^{\text {xxix }}$ Rachel Moseley ‘Makeover Takeover on British Television' Screen 41, 3, 2000, 299-314.

${ }^{\mathrm{xxx}}$ Charlotte Brunsdon, Catherine Johnson, Rachel Moseley and Helen Wheatley, 'Factual

Entertainment on British Television: The Midland TV Research Group's 8-9 Project'

European Journal of Cultural Studies 4, 1, 2001, 29-62.

${ }^{\text {xxxi }}$ SxMOA/1/1/14/8/1 Bulletin No 30 August 1949.

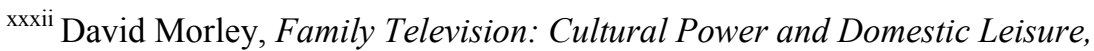

Routledge,1986; James Lull, Inside Family Viewing: Ethnographic Research On Television Audiences, Routledge, 1990

xxxiii Hazel Collie ‘Television for Women: Generation, Gender and the Everyday’ Unpublished PhD Thesis, De Montfort University, 2014.

${ }^{\text {xxxiv }}$ Henri Lebevre Critique of Everyday Life, Verso, 1984, p. $73 *$ check this is right version! ${ }^{x x x v}$ Rita Felski Doing Time: Feminist Theory and Postmodern Culture, New York University Press, 2000, p. 92.

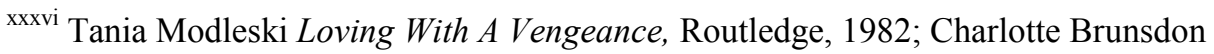
'Crossroads: Notes on Soap Opera Screen 22 (4): 1981, 32-47 
MOSELEY, WHEATLEY AND WOOD: 31

xxxvii Christine Geraghty, 'Exhausted and Exhausting: Television Studies and British Soap

Opera in Brett Mills, 'Invisible Television', Critical Studies in Television 5 (1), 2011.

xxxviii Felski, Doing Time, 2000, 93.

xxxix Ibid, 93

${ }^{\mathrm{xl}}$ See also Brunsdon, The Feminist, The Housewife.

LAST 